\title{
Interest-Rate Deregulation
}

Recently, interest-rate restrictions on most deposit accounts at banks and thrifts were eliminated. With the introduction of Money Market Deposit Accounts (MMDAs) and Super-NOWs, interest-rate ceilings on short-term deposits (in excess of $\$ 2500$ ) were effectively eliminated. Further, the October 1 deregulation of time deposits with maturities of 32 days to $2 \frac{1}{2}$ years has completed the deregulation of rates on long-term accounts. Although some interest-rate ceilings and other restrictions still exist (for example, interest-rate ceilings on passbook savings and NOW accounts), the interest rates that banks and thrifts can pay to attract funds are now largely unregulated and will be determined by market forces. Although the magnitude of the economic impact of interest-rate deregulation may not be known for years, it is likely that deposit rates will be higher. However, contrary to conventional wisdom, higher deposit rates will not lead to higher loan rates and loan rates may even be somewhat lower than they would have been without deregulation. This Letter discusses why interest-rate deregulation is expected to have these effects.

\section{Is the conventional wisdom wrong?}

Many analysts believe that interest-rate deregulation will lead to higher interest rates for borrowers because it will increase the average interest cost of funds to banks and thrifts. For example, recent articles in The Wall Street Journal (November 7, 1983) and Business Week (November 28, 1983) claim that interest-rate deregulation has built at least a one percentage point increase into the structure of loan rates, and that deregulation means an end to artificially low rates on mortgages and other consumer loans. The reasoning behind this claim apparently is that the higher interest costs banks and thrifts will have to pay for their funds will be passed on to their loan customers. However, this argument ignores three points. First, it is the marginal cost, i.e., the total incremental cost of attracting an additional dollar of deposits, that determines the interest rates that financial institutions charge on loans. Second, the interest cost of additional funds is just one component of their marginal cost. Finally, deregulation will not increase and may lower the marginal cost of deposits.

The conventional wisdom that loan rates will rise because of deregulation ignores a general principle of microeconomics: In a competitive industry, binding price controls can lead to a redistribution of income, but they cannot increase, and usually decrease, the quantities of scarce goods available. In the financial sector, regulation would reduce the supply of funds available to banks and thrifts if the effective rate of return on deposits were kept artificially low. As a result, depository institutions had to use other more costly ways to compensate: depositors in order to attract additional funds, had to charge their loan customers higher loan rates to ration the restricted supply of funds, or both. Thus, regulation did not make more funds available to lend, and did not reduce the cost of attracting additional funds. By the same token, deregulation should not be expected to increase the marginal cost of funds or reduce their quantity. Deregulation will not lead to an increase in loan rates.

\section{Supply of and demand for deposits}

The supply of deposits to the regulated financial sector is responsive to the differential between the rate of return on deposits and returns on unregulated alternatives such as Treasury securities. A fall in the rates on alternative investments reduces their attractiveness compared to deposits, and leads to an inflow of funds to depository institutions. Similarly, an increase in their rates causes depository institutions to lose deposits as the alternative investments become more attractive. For example, banks and thrifts were particularly hard hit by deposit out- 
Opinions expressed in this newsletter do nol necessarily reflect the views of the management of the Federal Reserve Bank of San Francisco. or of the Buard oi Covernors of the Federal Reserve System.

flows in 1981 when the T-bill rate rose to 17 percent.

Evidence on the interest-rate sensitivity of regulated deposits is presented in Chart 1 where the percent of total bank and thrift deposits accounted for by passbook savings accounts is compared to the 3-month T-bill rate (a market-determined rate). This chart shows that when market rates rise, passbook savings fall as a percent of total deposits. This inverse relationship has been particularly strong since 1978 when money market mutual funds became widely accepted. The rise in market interest rates since 1977 has led to a steep decline in passbook savings from almost 40 percent of total deposits in 1977 to less than 20 percent in 1982 . In absolute terms, passbook savings have fallen from about $\$ 500$ billion in 1978 to less than $\$ 350$ billion in 1982 .

The demand by banks and thrifts for deposit funds is negatively related to the marginal cost of these funds because higher marginal costs mean higher interest rates for their loan customers, who in turn cut back on the amount they are willing to borrow. In the absence of deposit-rate regulation, the inter . action of the supply of and demand for deposits would determine the rate paid on them and the quantity attracted by depository institutions.

In contrast, a binding deposit-rate ceiling (which could not be circumvented), by lowering the rate paid on deposits, would reduce the quantity of deposits the public was willing to supply to banks and thrifts. A smaller quantity of funds supplied would mean an artificial shortage of funds to lend. Borrowers from banks and thrifts in turn would be willing to pay higher rates in order to get part of the smaller supply of funds. Thus, binding interest-rate ceilings, by raising loan rates and at the same time lowering deposit rates, would create a powerful profit incentive for banks and thrifts to compete for additional funds by circumventing the ceilings.
Were the ceilings circumvented?

Regulated financial institutions in fact developed two important means of circumventing interest-rate ceilings. One way was to offer extra "non-priced" services, such as longer business hours, more branches, and "free" checking accounts. The other way was to attract deposits in the form of largedenomination $(\$ 100,000) \mathrm{CDs}$ (which have not been subject to interest-rate ceilings since the early 1970s).

Some non-priced services would be offered even in the absence of regulation because of tax considerations and the costs involved in charging for some services. However, it is likely that the quantity of non-priced services offered under regulation exceeded what banks and thrifts would offer in the absence of regulation. For example, Bank of America recently announced it will close 120 branches and many banks are now charging for services that were previously free. In addition, financial institutions have shifted dramatically to using interest rates to compete for deposits since deregulation by offering, for example, high rates on Money Market Deposit Accounts. This suggests that offering non-priced services was a relatively costly way to compete, and that, as a result, the cost of attracting additional funds was higher under regulation. If interest-rate competition were not a less costly way of attracting deposits, financial institutions would not have shifted so dramatically from non-price to price competition.

The fact that deregulation has led to reductions in non-priced services and increases in deposit rates means that at least some of the non-price competition was socially wasteful - that the cost of providing these services exceeded the value that the depositors placed on them. Deregulation, by eliminating this waste, will benefit both depositors and loan customers.

However, the divergence between market rates and interest-rate ceilings varies over the business cycle. Thus, since it is difficult 

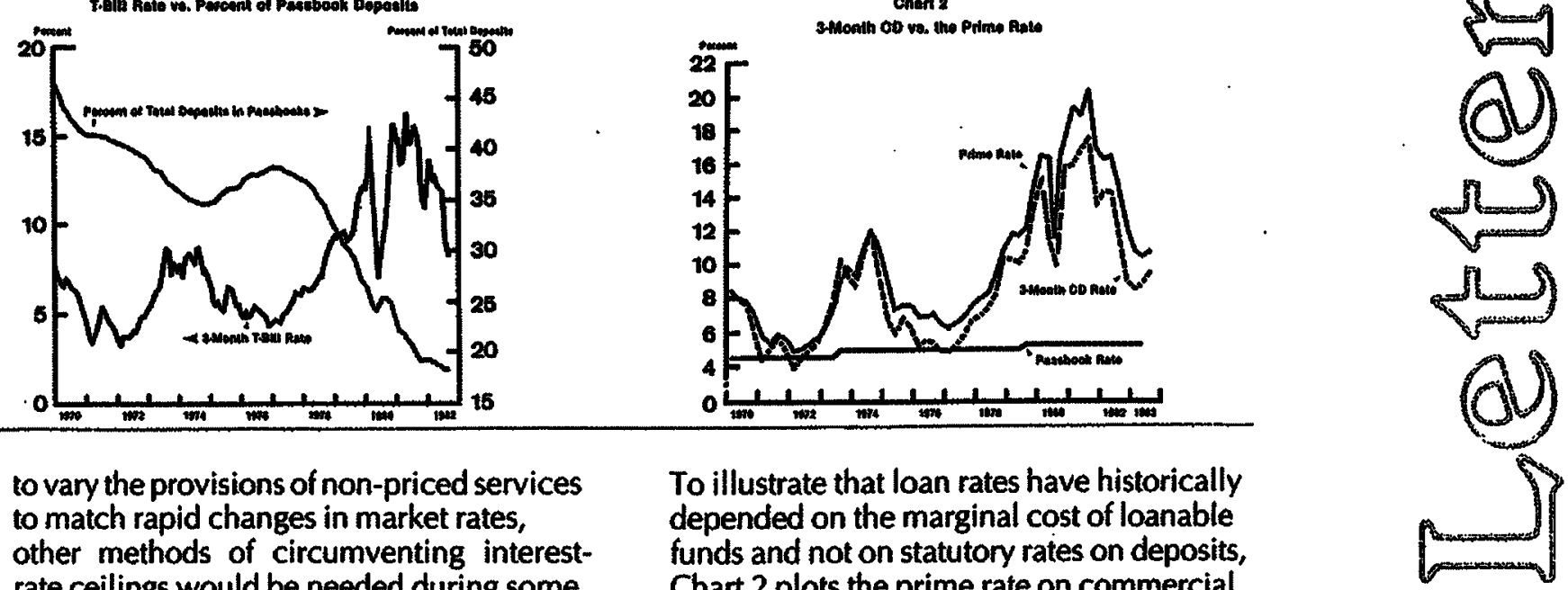

to vary the provisions of non-priced services to match rapid changes in market rates, other methods of circumventing interestrate ceilings would be needed during some parts of the business cycle. Large CDs were just such a method. Large banks widely used large CDs to circumvent interest-rate ceilings, although small banks and thrifts were less able to tap this market. Since there have been no interest-rate ceilings on these accounts since the early 1970s, financial institutions could use interest-rate competition to attract these types of deposits. However, it is likely that the marginal costs of such funds were higher because of regulation. One reason is that since the late 1970s, money market mutual funds were an important conduit for small deposits that were aggregated and then invested in large CDs. However, the transactions costs of consolidating funds that would have been deposited in banks in the absence of interest-rate ceilings and then depositing them in banks as CDs must be larger than having the banks directly attract such funds by paying market rates. The fact that the fraction of total deposits in CDs has declined after deregulation supports this hypothesis.

\section{Lower marginal costs}

Since both of these means for circumventing interest-rate ceilings were probably more costly than interest-rate competition, deregulation will certainly not raise and may even lower the marginal cost of raising funds. Since the marginal cost of funds determines the rate charged for loans, the loan rate also will not increase and may decrease somewhat under deregulation. How large this effect will be is an empirical question.
To illustrate that loan rates have historically depended on the marginal cost of loanable funds and not on statutory rates on deposits, Chart 2 plots the prime rate on commercial loans, the 3-month $C D$ rate, which approximates the marginal cost of deposits, and the passbook ceiling rate. This chart shows that the prime rate and the $C D$ rate move together very closely. If the interest rate on loans were primarily determined by the regulated deposit rate, we would not expect the loan rate to be so closely correlated with a market-determined rate such as the $C D$ rate.

\section{Conclusions}

Regulation had the effect of limiting the ability of banks and thrifts to perform their valuable economic function as financial intermediaries by limiting their ability to use deposit-rate competition to attract deposits. With deregulation, the competition for deposits will be more efficient because regulated institutions will be free to compete using price, i.e., deposit interest rates. Consequently, rates paid on deposits that were previously regulated will be higher and more funds will be attracted to regulated financial intermediaries. These higher deposit rates, however, will not lead to higher loan rates, and loan rates may even be somewhat lower. In addition, the socially wasteful non-price competition among financial institutions due to interest-rate regulation will be eliminated and funds will be more efficiently allocated to borrowers. Thus, deregulation will have important benefits for both savers and borrowers as well as for the economy as a whole.

Michael C. Keeley
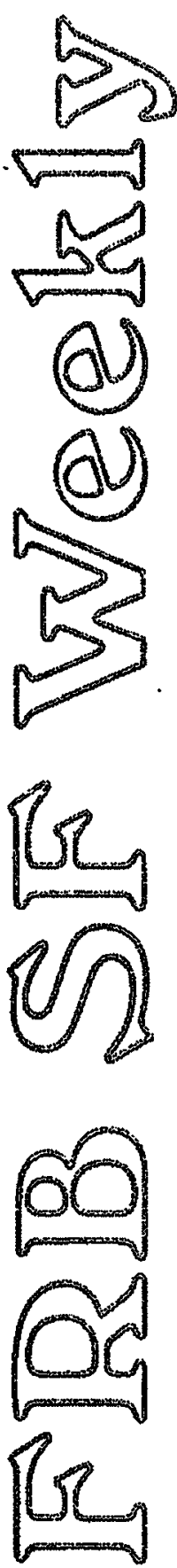


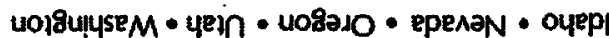
IEREH • E!UOIgEJ • EUOZ!W • EYSE|Y

\section{(1)}

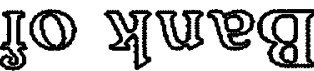

\section{3ヘ}

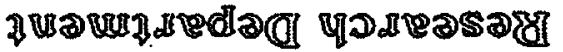

\section{BANKING DATA-TWELFTH FEDERAL RESERVE DISTRICT} (Dollar amounts in millions)

\begin{tabular}{|c|c|c|c|c|}
\hline $\begin{array}{l}\text { Selected Assets and Liabilities } \\
\text { Large Commercial Banks }\end{array}$ & $\begin{array}{c}\text { Amount } \\
\text { Outstanding } \\
12 / 28 / 83\end{array}$ & $\begin{array}{l}\text { Chainge } \\
\text { from } \\
12 / 21 / 83\end{array}$ & $\begin{array}{l}\text { Chat } \\
\text { ye } \\
\text { Dollar }\end{array}$ & $\begin{array}{l}\text { from } \\
\text { go } \\
\text { Percent }\end{array}$ \\
\hline $\begin{array}{l}\text { Loans (gross, adjusted) and investments* } \\
\text { Loans (gross, adjusted) - total\# } \\
\text { Commercial and industrial } \\
\text { Real estate } \\
\text { Loans to individuals } \\
\text { Securities loans } \\
\text { U.S. Treasury securities* } \\
\text { Other securities* } \\
\text { Demand deposits - total\# } \\
\text { Demand deposits - adjusted } \\
\text { Savings deposits - totalt } \\
\text { Time deposits - total\# } \\
\text { Individuals, part. \& corp. } \\
\text { (Large negotiable CD's) }\end{array}$ & $\begin{array}{r}165,522 \\
145,328 \\
44,261 \\
57,801 \\
25,967 \\
3,470 \\
7,821 \\
12,371 \\
45,098 \\
30,355 \\
65,937 \\
70,404 \\
64,321 \\
17,319\end{array}$ & $\begin{array}{r}186 \\
167 \\
294 \\
58 \\
252 \\
116 \\
-\quad 26 \\
45 \\
1,679 \\
301 \\
-\quad 91 \\
-\quad 78 \\
-\quad 118 \\
-\quad 170\end{array}$ & $\begin{array}{r}1,228 \\
2,383 \\
-\quad 1,556 \\
713 \\
1,958 \\
643 \\
834 \\
-\quad 1,768 \\
1,959 \\
629 \\
21,444 \\
-18,219 \\
-14,352 \\
-13,184\end{array}$ & $\begin{array}{r}0.7 \\
1.5 \\
-\quad 3.4 \\
1.2 \\
8.2 \\
22.7 \\
11.6 \\
-\quad 12.5 \\
.4 .5 \\
.2 .1 \\
48.2 \\
-\quad 20.6 \\
-18.2 \\
-\quad 43.2\end{array}$ \\
\hline $\begin{array}{l}\text { Weekly Averages } \\
\text { of Daily Figures }\end{array}$ & $\begin{array}{l}\text { Week ended } \\
12 / 28 / 83\end{array}$ & $\begin{array}{l}\text { Week ended } \\
12 / 21 / 83\end{array}$ & \multicolumn{2}{|c|}{$\begin{array}{l}\text { Comparable } \\
\text { year-ago period }\end{array}$} \\
\hline $\begin{array}{l}\text { Mernber Bank Reserve Position } \\
\text { Excess Reserves (+)/Deficiency (-) } \\
\text { Borrowings } \\
\text { Net free reserves (+)/Net borrowed(-) }\end{array}$ & $\begin{array}{l}61 \\
42 \\
20\end{array}$ & & & $\begin{array}{r}116 \\
9 \\
107\end{array}$ \\
\hline
\end{tabular}

- Excludes trading account securities.

\# Includes items not shown separately.

+ Includes Money Market Deposit Accounts, Super-NOW accounts, and NOW accounts.

Editorial comments may be addressed to the editor (Gregory Tong) or to the author .... . Free copies of this and other Federal Reserve publications can be obtained by calling or writing the Public Information Section, Federal Reserve Bank of San Francisco, P.O. Box 7702, San Francisco 94120. Phone (415) 974-2246. 